\title{
简议建筑工程项目施工现场管理的重要意义及其措施
}

向庭江

天津天一建设集团有限公司

DOI:10.18686/bd.v2i6.1415

[摘 要] 建筑工程项目施工多为露天、高空作业, 并且规律性差及隐患多, 因此对必须加强对建筑工程项目施工现场进行 严格管理。基于此, 本文阐述了简述了建筑工程项目施工现场管理的主要内容, 对建筑工程项目施工现场管理的重要意义 及其措施进行了论述分析。

[关键词] 建筑工程项目; 施工现场管理; 内容; 意义; 措施

施工现场管理决定着建筑工程质量和建筑企业经济效 益, 其是建筑工程管理的重要内容, 并且对于建筑工程项目 建设的顺利进行具有重要作用。

1 建筑工程项目施工现场管理的主要内容分析

建筑工程项目施工现场管理内容主要有:

1.1 现场材料设备管理。第一、材料管理,其是影响建筑 工程经济效益的重要环节, 建筑工程项目施工管理首先要 对施工材料进行管理,通过材料供应商资质审核、对进场材 料的现场抽样及检测、材料存放管理等保障施工用材料符 合设计要求,为保障工程施工质量打下基础。现场施工各阶 段所用材料, 必须具有产品合格证明、各项检测符合设计及 合同要求等,从而保障工程施工质量。第二、施工设备管理。 施工设备是建筑工程建设的重要工具, 随着科学技术的不 断发展, 现代新的施工设备在建筑工程建设中得到广泛使 用。建设单位应设置专门的安全监管人员会同监理公司共 同督促施工单位加强建筑工程项目施工设备管理。从建筑 工程设备的保养与维护抓起, 从而保障施工设备能够稳定 的运行, 以此保障建筑工程建设施工进度。同时注重施工设 备操作人员管理, 严格按照设备操作规程进行操作, 降低违 规操作造成的设备损伤与事故的发生率。避免由于违规操 作造成设备损伤而影响工程进度, 从而降低施工企业施工 成本, 提高建筑企业经济效益。在进行施工设备管理时, 严 格执行“人机固定原则”定机、定人、定岗。

1.2 施工成本管理。根据现代施工成本管理理念, 建设 单位实施成本管理必须建立成本管理体系, 以明确的责任 制度促进成本管理的实施。将施工过程各个部门与人员按 照施工组织架构与成本管理的关系明确职责与成本管理责 任,使施工过程的全体人员明确自身的成本管理责任, 达到 怎样的成本控制目标, 以此促进施工成本管理的实施。

1.3 现场施工人员管理。人是影响建筑工程项目施工质 量的直接因素, 为了严格执行施工管理规定, 有效进行施工 人员管理,保障工程施工质量, 督促施工企业必须建立健全 的人员管理体系。以完善的规章制度、健全的工程组织机 构、提高专业技术人才比例等方式为工程施工质量奠定基 础。在进行人员管理过程中, 主要针对工程施工操作、安全
规程执行等进行管理。

\section{2 建筑工程项目施工现场管理的重要意义}

建筑工程项目施工现场管理的重要意义主要表现为:

2.1 有利于消除建筑工程的安全隐患, 保证施工人员安 全。由于施工现场多工种联合作业、露天高空作业多、人员 流动大, 是事故隐患多发地段, 而加强施工现场管理能有效 降低事故发生率。

2.2 有利于保障建筑工程质量。建筑施工企业系列标准 的贯彻控制, 建立质量保证体系, 突出施工现场质量控制, 要求施工企业把质量管理的重点放在施工现场。另外,减少 或消除施工现场的无效劳动,改善人、物、在施工现场的结 合状态, 减少施工材料的消耗, 为施工企业节支增收。工期 的拖延或赶工都会直接影响到施工的质量、安全和成本因 素。

2.3 有利于实现施工现场管理目标。加强建筑工程建设 中的施工现场管理可以严格控制施工进度及材料管理和使 用有条不絮,使施工安全高效运行。有效地现场管理使得施 工现场整洁美观, 还要注意环保文明, 不对周边产生过多的 不良影响。良好的现场管理是建筑施工现场管理工作的重 要性,也是提升企业竞争力的必不可少的重要条件。

2.4 有利于提高建筑工程的经济效益。建筑施工单位经 营活动就是将合格的建筑产品提供给市场和社会, 从中获 取利润。只有提供质量好、工期和造价都合理的建筑产品, 才能得到市场认可。

\section{3 加强建筑工程项目施工现场管理的措施}

3.1 合理编制现场施工方案。建筑工程项目现场施工组 织设计是指导施工准备以及施工全过程的技术文件, 其中 的内容主要根据施工的性质、规模、结构、施工复杂程度、工 期要求、当地的实际条件而确定。一份好的施工计划方案, 要科学的概括人力、物力、财力的合理搭配,优化资源配置。 施工组织设计的编制对工程造价有着很大的影响, 不同的 施工方案也需要投人不同的资金,进行不同的成本管理。因 此, 施工前, 应组织包括技术、质量、施工、机械、材料、劳力 等相关人员, 一起采纳与研究施工计划的制定, 针对工程实 际情况编制相应的施工方案。 
3.2 加强建筑工程现场施工安全管理。建筑工程安全管 理是建筑管理的重要内容, 在建筑工程现场施工过程中, 为 了保障建筑工程项目建设的顺利实施, 必须加强建筑工程 安全管理,防止建筑工程安全事故发生, 从而保障建筑工程 项目建设的社会经济效益。主要表现为:

3.2.1 建立健全现场安全管理责任制。建筑工程现场安 全管理需要制定合理安全目标, 同时实行责任制, 签订安全 责任书, 各司其责, 层层负责, 落实责任到人, 将安全生产全 面贯彻下去。同时要加强对安全责任的检查力度, 由企业负 责人作为第一责任人,项目经理对项目安全全面管理。

3.2.2 严格建筑工程安全检查。建筑工程安全检查是保 证安全生产管理一个至关重要的环节, 也是安全生产管理 工作的重中之重。要定时地对施工现场进行安全排查, 要对 各个施工环节进行把关, 要保证每个施工环节都是遵守安 全生产规章制度的,一旦发现有违法违规施工的现象,一定 要及时地制止, 并在第一时间采取措施进行补救。比如, 要 加强对现场脚手架施工的检查, 高支模工程的检查和各项 机械设备的检查,防范高空坠物、机械伤人等安全事故的发 生, 同时要建立施工人员安全生产奖惩机制。

3.3 严格施工原材料及施工机械设备管理。主要表现为

3.3.1 基于施工原材料的重要性。作为施工企业, 必须 切实加强对原材料质量的控制。同时还应确保配比的科学 性, 相同材料的配比不同,其所带来的结果截然不同,所以 必须在控制原材料质量的同时还应加强对原材料配比的控 制, 尤其混凝土配合比,必须得到的有效的控制。

3.3.2 严格施工机械设备的安全管理。建筑工程项目施 工机械是施工现场管理的重要内容, 为了促进工程质量的 有效提升, 作为新时期背景下的施工企业, 就必须加大投资 力度, 着力更新施工机械设备, 对大型机械设备也可采用租 贷或融资租赁的方式以缓解一次性投资过大的压力, 并切 实加强对施工机械设备的安全管理, 促进施工机具安全高 效的运行, 从而通过施工机械设备的安全管理, 为施工质量 的控制奠定坚实的基础。

3.4 做好技术交底工作。建筑工程项目施工企业必须组 织全体管理人员积极主动地参与到施工技术交底工作中 来。就施工来看, 主要包括了土方开挖、回填、钢筋模板施 工、混凝土施工、砌体施工和抹灰施工、外保温施工、钢结构
吊装、水电管线施工、消防系统施工以及装饰装修等。为了 保障各阶段施工安全, 因此必须进行及时有效的交底, 并结 合施工设计图纸及施工现场对每个分项工程进行全面交底 工作。

3.5 加强现场施工成本管理。成本管理作为建筑企业管 理工作的重要组成部分, 不仅能有效提高建筑企业的管理 水平, 还能使企业获得更好的效益。因此必须加强管理人员 及施工人员的成本管理意识, 提高全员管理成本的能力。首 先, 项目经理必须高度具备成本管理的管理意识, 并协同各 个部门制定有效的成本管理策略; 其次, 必须强化项目部全 体成员的施工成本管理观念, 并加强对施工成本的核算, 及 时发现和解决施工成本管理过程中存在的问题。最后, 还要 加强对成本管理人员及施工人员的培训, 以增强其施工成 本管理的观念。

3.6 提升从业人员的综合素质。现场施工人员的素质直 接影响建筑工程质量, 只有不断提高施工人员的专业水平 及其综合管理能力, 才能提升整体管理水平。但是建筑施工 人员数额庞大, 且年龄、文化、技术水平良莠不齐, 相差甚 多, 无疑为强化其知识技能的实施带来了难度。为每个级别 的施工人员量身制定科学、合理的培训计划和目标, 比如对 于新人职的施工人员首先要灌输安全第一、认真负责、遵纪 守法的思想, 还要进行专业技术的培训, 防止出现严重的施 工差错及事故。

\section{4 结束语}

综上所述, 施工现场管理对建筑工程建设施工的顺利 进行具有重要影响, 并且加强建筑工程项目施工现场管理 可以使施工现场井然有序, 有利于保障施工人员安全, 因此 对建筑工程项目施工现场管理进行分析具有重要意义。

\section{参考文献:}

[1]徐箭,康建军.试探建筑工程土木施工现场管理的优 化策略 [J].江西建材,2017(10):241+243.

[2]陈晨. 建筑工程项目管理中的施工现场管理分析 [J].建材与装饰,2017(42):103-104.

[3]王希吉. 建筑工程施工安全管理研究 [J].绿色环保 建材,2018(01):214.

[4]余俊安, 齐雨迪. 浅谈建筑工程施工技术及其现场施 工管理[J].建材与装饰,2018(01):134-135. 